\title{
Maize yield performance altered by trinexapac-ethyl rates and plant population ${ }^{1}$
}

\author{
Luiz Fernando Pricinotto ${ }^{2}$, André Sampaio Ferreira ${ }^{3 *}$ (D) Inês Cristina de Batista Fonseca ${ }^{3}$, \\ Leandro Teodoski Spolaor ${ }^{4}$, Claudemir Zucareli ${ }^{3}$
}

$10.1590 / 0034-737 \times 202168050005$

\begin{abstract}
Increases in plant density associated with the use of plant growth regulators, aside from modifying the plant architecture, can also change the maize yield performance. This study aims to investigate the yield components and grain yield of maize hybrids with contrasting leaf architecture, in response to different plant populations and trinexapacethyl rates (TE). Field experiments were conducted in two growing seasons, in a (5 x 5) factorial randomized block design. The treatments consisted of: five plant population $\left(40,60,80,100\right.$, and 120 thousand plants ha $\left.{ }^{-1}\right)$ and five TE rates $\left(0,100,200,300\right.$, and $\left.400 \mathrm{~g}_{\text {a.i. }} \mathrm{ha}^{-1}\right)$, with four replications, using the hybrids $2 \mathrm{~B} 710 \mathrm{HX}$ and Status TL. We evaluated the number of rows per ear, ear length, number of grains per row, 1000-grain mass, and yield. An increased plant density reduces ear length, number of grains per row and 1000-grain mass, without changing the number of grain rows per ear. TE rates increases ear length and number of grains per row and reduces 1000-grain mass, mainly under favorable cultivation conditions. TE interacts with the plant density, changing the maize yield components with increases in grain yield, but these gains variy, according to the environment and genotype characteristics.
\end{abstract}

Keywords: Zea mays L; plant architecture; plant population; bioregulator; growth regulator.

\section{INTRODUCTION}

Maize grain yield can be increased by maximizing the photosynthetic efficiency, by intensifying the solar radiation interception of the canopy (Marchão et al., 2006). One of the ways of improving interception is an elevation of the plant density, thus augmenting the leaf area of the canopy (Sangoi et al., 2013).

The management of plant density in maize cultivation is a practice with a major effect on grain yield. The reason is that maize has no efficient compensation mechanisms of spaces, since tillering is scarce and inefficient, the leaf expansion capacity is low and prolificacy poor (Sangoi et al., 2011).

However, very high densities can negatively affect the crop, resulting in blanched plants with thinner stems, ultimately favoring lodging. In addition, excessively high densities are also harmful for causing an increase in intraspecific competition, reducing components such as ear length, the number and/or grain mass per ear and 1000 grain mass (Brachtvogel, et al., 2009; Sangoi et al., 2009).

Since increases in plant density are only favorable up to a certain limit, the implementation of complementary techniques, such as the use of growth regulators, can be a way to modify the architecture of maize plants, enabling the use of high densities.

Plant growth regulators influence the plant metabolism, and are applied to change the characteristics of leaf architecture and reduce the stem height, with a view to facilitating cultural practices, reducing the propensity to lodging, maximizing the absorption of solar radiation and thus, increasing grain yields (Zagonel \& Ferreira, 2013; Gong et al., 2021; Sangoi et al. 2020).

\footnotetext{
Submitted on May $27^{\text {th }}, 2019$ and accepted on March 23 $3^{\text {th }}, 2021$.

${ }^{1}$ This work is part of the first author's Doctoral Thesis.

${ }^{2}$ Secretaria de Estado da Agricultura e do Abastecimento, Departamento de Desenvolvimento Agropecuário, Cianorte, Paraná, Brazil. lfpricinotto@hotmail.com

${ }^{3}$ Universidade Estadual de Londrina, Departamento de Agronomia, Londrina, Paraná, Brazil. andresampaioferreira@gmail.com; inescbf@gmail.com; claudemircca@uel.br

${ }^{4}$ Universidade Estadual de Maringá, Departamento de Agronomia, Maringá, Paraná, Brazil. leandrotspolaor@hotmail.com

*Corresponding author: andresampaioferreira@gmail.com
} 
Trinexapac-ethyl is a plant growth regulator that interferes with the biosynthesis of gibberellic acid, drastically reducing the level of active gibberellic acid (GA1) by inhibiting 3â-hydroxylase, shortening the plant height (Davies, 1987).

For wheat, studies have shown that TE can reduce the propensity to lodging, as well as modify the plant leaf architecture, allowing better exploitation of the incident radiation and, consequently, providing yield increases (Zagonel \& Fernandes, 2007; Penckowski et al., 2009). Increments in grain yield of upland rice in response to TE application were reported by Nascimento et al. (2009) and Arf et al. (2012), with increments in the number of panicles $\mathrm{m}^{-2}, 100$-grain mass and hectoliter mass.

In Brazil, the commercial product containing TE is not registered for maize application, but recent studies are investigating the potential of this bioregulator for maize crop. Different TE rates and application times were tested on maize by Zagonel \& Ferreira (2013), with low influence of TE on the corn crop. However, the authors tested the TE rates and application times at fixed plant densities and spacing between rows, without evaluating the interaction with these aspects of crop management. On the other hand, Leolato et al. (2017) evaluated increased plant density associated with TE application in maize and observed a reduction in plant height and 1000-grain mass, but no yield increases.

In this context, this study aims to investigate the yield components and grain yield of maize hybrids with contrasting leaf architecture, in response to different plant densities and trinexapac-ethyl rates.

\section{MATERIAL AND METHODS}

The experiments were carried out in two growing seasons. In growing season 1 (2010/2011), the experiment was installed on a farm in the county of Cambé, Paraná (2303'25" S - 51 '17'53" W; 490 m asl, Latossolo Vermelho eutroférrico (LVe)) and in growing season 2 (2011/2012), on an experimental farm in Londrina, Paraná (2320'32" S $51^{\circ} 12$ '32" W; $540 \mathrm{~m}$ asl, Latossolo Vermelho distroférrico $(\mathrm{LVd}))$.

The no-tillage system was used in the experimental areas, where soybean was planted in the summer and wheat in the winter of the last growing season prior to the experiment Before initiating the experiments, soil samples were collected from the experimental areas, in the $0-0.20$ $\mathrm{m}$ layer, with the following chemical characteristics: Growing season $1-\mathrm{pH}_{\mathrm{CaCl} 2}=5.29 ; \mathrm{P}($ Mehlich 1$)=9.07 \mathrm{mg}$ $\mathrm{dm}^{-3} ; \mathrm{K}^{+}=0.38 \mathrm{cmol}_{\mathrm{c}} \mathrm{dm}^{-3} ; \mathrm{Ca}^{2+}=5.93 \mathrm{cmol}_{\mathrm{c}} \mathrm{dm}^{-3} ; \mathrm{Mg}^{2+}=$ $1.57 \mathrm{cmol}_{\mathrm{c}} \mathrm{dm}^{-3} ; \mathrm{Al}^{3+}=0.00 \mathrm{cmol}_{\mathrm{c}} \mathrm{dm}^{-3} ; \mathrm{H}^{+}+\mathrm{Al}^{3+}=4.09$ $\mathrm{cmol}_{\mathrm{c}} \mathrm{dm}^{-3} ; \mathrm{CEC}_{\text {effective }}=8.21 \mathrm{cmol}_{\mathrm{c}} \mathrm{dm}^{-3}$; base saturation $(\mathrm{V})=66.7 \%$ and organic matter $=26.16 \mathrm{~g} \mathrm{dm}^{-3}$ and in growing season $2-\mathrm{pH}_{\mathrm{CaCl} 2}=5.26 ; \mathrm{P}($ Mehlich 1$)=9.08 \mathrm{mg}$ $\mathrm{dm}^{-3} ; \mathrm{K}^{+}=0.30 \mathrm{cmol}_{\mathrm{c}} \mathrm{dm}^{-3} ; \mathrm{Ca}^{2+}=4.28 \mathrm{cmol}_{\mathrm{c}} \mathrm{dm}^{-3} ; \mathrm{Mg}^{2+}=$ $1.05 \mathrm{cmol}_{\mathrm{c}} \mathrm{dm}^{-3} ; \mathrm{Al}^{3+}=0.00 \mathrm{cmol}_{\mathrm{c}} \mathrm{dm}^{-3} ; \mathrm{H}^{+}+\mathrm{Al}^{3+}=3.37$ $\mathrm{cmol}_{\mathrm{c}} \mathrm{dm}^{-3} ; \mathrm{CEC}_{\text {effective }}=5.83 \mathrm{cmol}_{\mathrm{c}} \mathrm{dm}^{-3}$; base saturation $(\mathrm{V})=62.5 \%$ and organic matter $=14.24 \mathrm{~g} \mathrm{dm}^{-3}$.

The mean rainfall and mean maximum and minimum temperatures in the experimental periods were recorded (Figure 1).

In each growing season, two experiments were carried out, with cultivars with different leaf architecture, sown in adjacent areas. The cultivar 2B710 HX has plane leafs with greater lenght and width than the STATUS TL cultivar that has more upright leafs. The experiments were arranged in randomized complete blocks, in a factorial $5 \mathrm{x}$ 5 design, with four replications. The response of five maize populations $(40,60,80,100$, and 120 thousand plants ha$\left.{ }^{1}\right)$ to five TE rates $\left(0,100,200,300\right.$, and $400 \mathrm{~g}$ a.i. ha $\left.{ }^{-1}\right)$ was analyzed. The TE used was the commercial product Moddus ${ }^{\circledR}$, at a concentration of $250 \mathrm{~g} \mathrm{~L}^{-1}$ a.i.

The experiments were sown on October 12, 2010 and October 9,2011, within the period established for maize in this agricultural zone. Approximately 20 days after sowing, the seedlings were thinned by hand to the pre-established population density.

The growth regulator was applied in stage V6, according to the scale proposed by Ritchie et al. (2003), by foliar spraying with a pressurized backpack sprayer $\left(\mathrm{CO}_{2}\right)$, equipped with a twin spray nozzle with air induction, at constant pressure and flow of $150 \mathrm{~L} \mathrm{ha}^{1}$.

Fertilization at planting consisted of $250 \mathrm{~kg}$ of nitrogen, phosphorus and potassium formulation $\left(8 \% \mathrm{~N}-28 \% \mathrm{P}_{2} \mathrm{O}_{5}\right.$ $-16 \% \mathrm{~K}_{2} \mathrm{O}$ ), according to the results of the soil analysis. Sidedressing was applied between stage V4 and V6, at a rate of $150 \mathrm{~kg} \mathrm{~N} \mathrm{ha}^{-1}$, using urea as source (45\%).

The cultural practices, weeding, and pests and disease control were performed according to the official technical recommendations for the crop. The evaluated plot had a total area of $9 \mathrm{~m}^{2}$, and the experimental plot consisted of six 6-m rows spaced $0.45 \mathrm{~m}$ apart.

After the end of the crop cycle, the maize ears were harvested from the useful plot area, and 10 random ears were separated to assesses the yield components. The ear length (EL), number of grain rows per ear (NGE) and number of grains per row (NGR) were evaluated.

After threshing all the ears of the evaluated area of each plot, the 1000-grain mass (TGM) and grain yield were measured. The 1000-grain mass was determined according to the methodology proposed by Brasil (2009), and yield by weighing the grains produced, and both masses were corrected to a moisture content of $130 \mathrm{~g}$ of water per kilogram grain.

The data was submitted to the response surface analysis that is adequate when the factors are quantitative and the objective is to find a combination of the factors 
leading to optimum conditions, in this case, the optimal combination of plant population and doses of trinexapacethyl. The polynomial model of the quadratic type with crosswords was tested, according to Equation 1:

$\mathrm{Y}=\beta_{0}+\beta_{0} x_{1}+\beta_{0} x_{2}+\beta_{0} x_{1}^{2}+\beta_{0} x_{2}^{2}+\beta_{0} x_{1} x_{2}$

Student's t-test was performed for significance of the coefficients of the model, at $5 \%$ probability. When the non-significance of one or more coefficients was verified, the model was again adjusted with significant terms. The analysis and diagram construction were performed with software STATISTICA $12^{\circledR}$.

\section{RESULTS AND DISCUSSION}

The technical recommendations cannot be used for a given crop in a general way, mainly in cases where a large variety of cultivars are used. Currently, cultivar-specific managements tend to be developed, as it is being done, e.g., for TE application to wheat, where the growth regulator rate is adapted to the response of each cultivar (Zagonel \& Fernandes, 2007). For this reason, the results were analyzed separately for each hybrid.

The number of grain rows per ear was not significantly influenced by the factors plant density and TE rates, regardless of the hybrid and growing season. This finding confirms the results of Zagonel \& Ferreira (2013). The lack of response of this variable to the factors studied here was due to the fact that this characteristic is strongly determined by genotype and less by the environment.

The increase in plant density led to a reduction in maize ear length, independent of the growing season and the hybrid (Figure 2). The same pattern was mentioned in studies of Brachtvogel et al. (2009) and Lana et al. (2014), since the increase in the number of plants per area leads to a greater number of ears per area, but with smaller ears and less grains, due to the greater competition for the resources of the environment caused by the density.
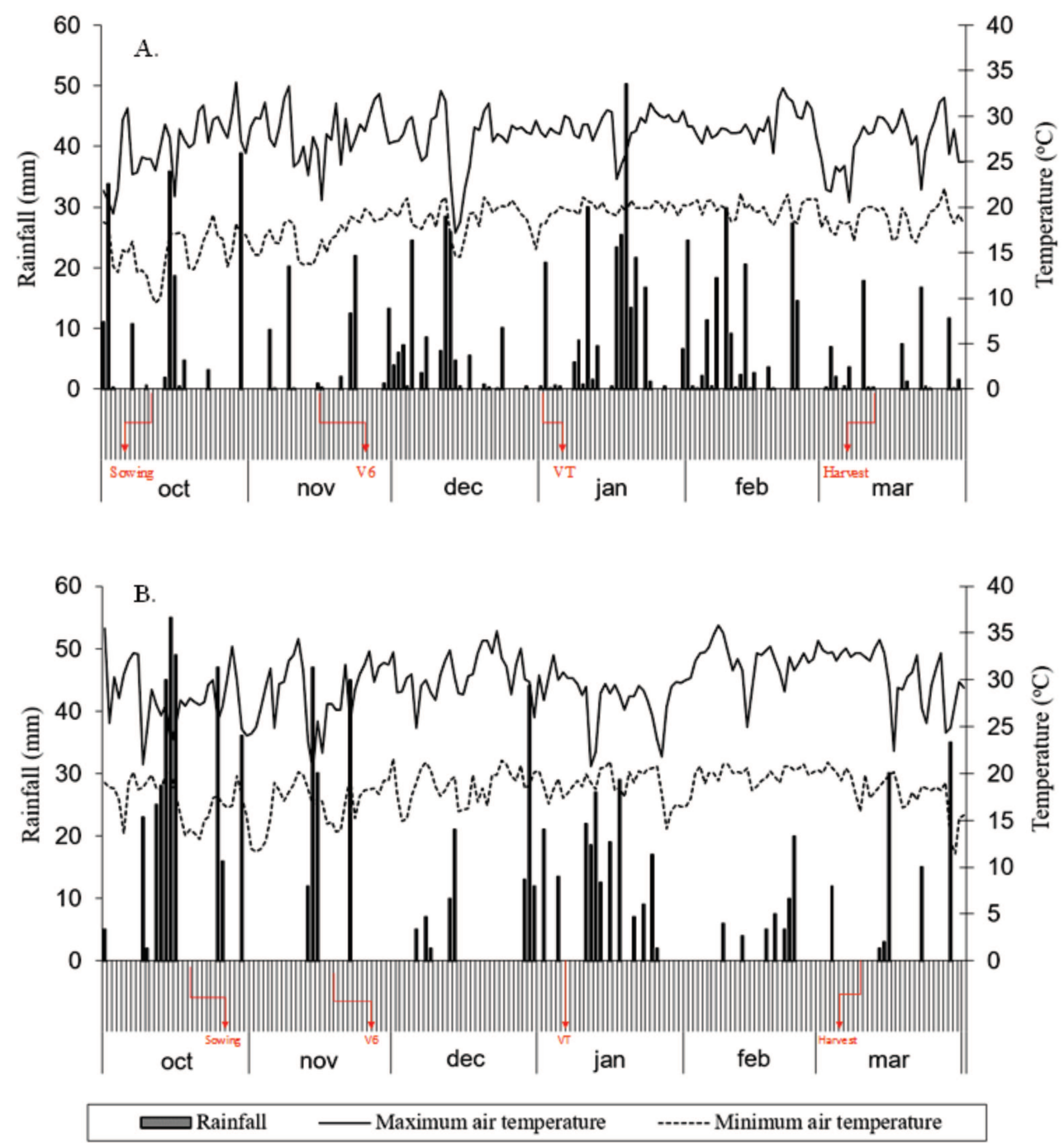

Figure 1: Meteorological data of rainfall, daily maximum and minimum temperatures. (A) 2010/2011 growing season, Cambé-PR. (B) 2011/2012 growing season, Londrina-PR. 
Trinexapac-ethyl increased ear length in the hybrids 2B710 HX and STATUS TL in growing season 1 (Figures $2 \mathrm{a}$ and $2 \mathrm{c}$ ). The highest growth regulator rates promoted length increases of 0.68 and $0.80 \mathrm{~cm}$ per ear, respectively. No effect of TE on ear length was observed in growing season 2.

As observed for ear length, the number of grains per row also declined in response to a higher number of plants per hectare (Figure 3).

In line with the observations for ear length, a linear increase in the number of grains per row was observed with increasing TE rates for both hybrids in growing season 1 (Figures $3 \mathrm{a}$ and $3 \mathrm{c}$ ). The same was observed in growing

(a)

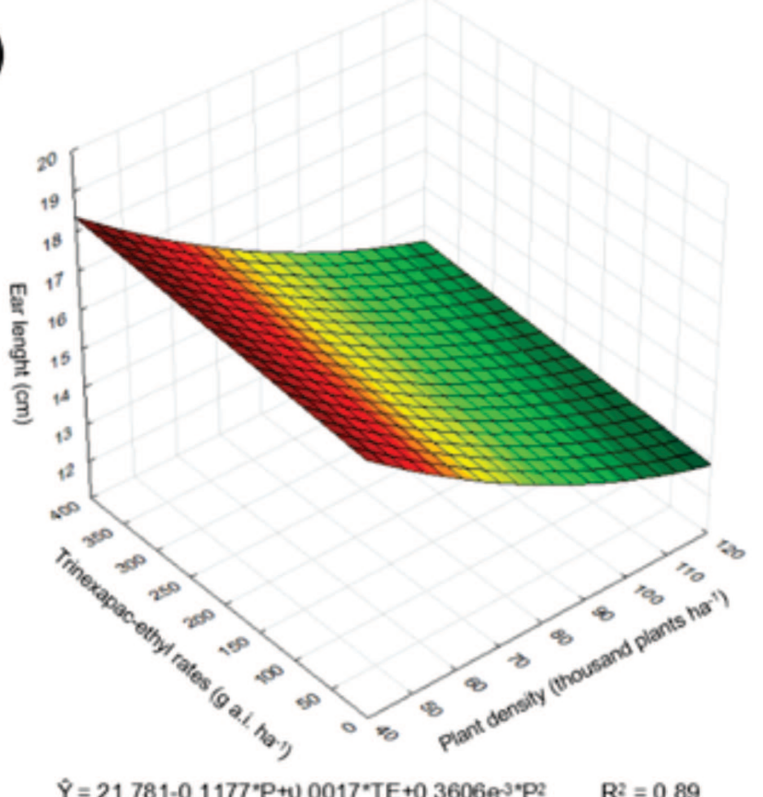

(c)

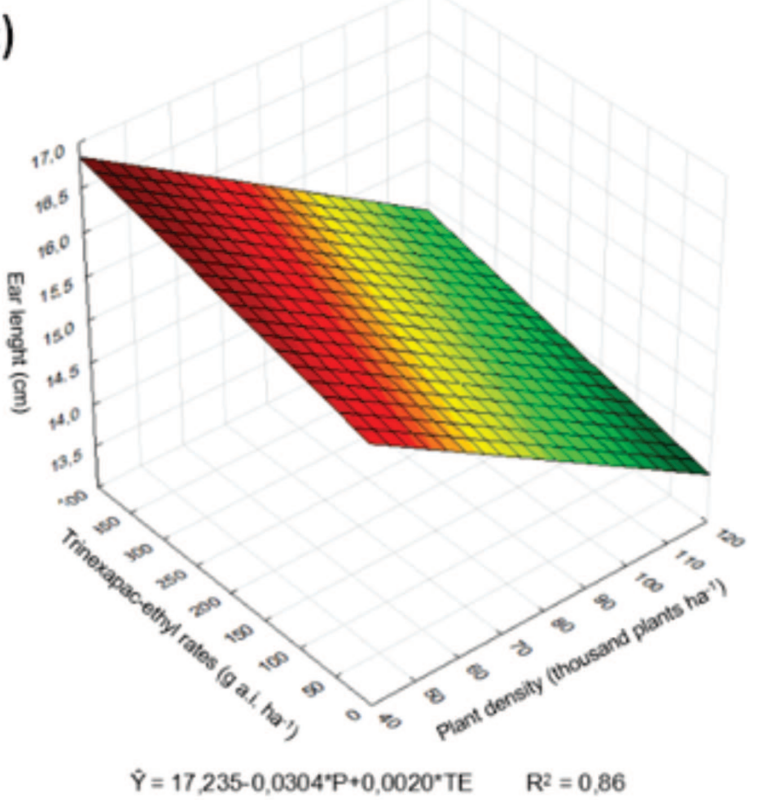

seasons 2 for hybrid STATUS TL (Figure 3d), whereas no effect of the growth regulator on this characteristic was detected for hybrid 2B710 HX.

No effect of TE rates and application times on the number of grains per row of the hybrids STATUS TL and MAXIMUS TLTG were observed by Zagonel \& Ferreira (2013), who ascribed this to an absence of effect of the growth regulator on plant height and other morphological characteristics. However, it is worth mentioning that in the above study, a fixed plant density (around 67 thousand plants $\left.\mathrm{ha}^{-1}\right)$ and spacing between planting rows $(0.8 \mathrm{~m})$ were used, explaining the differences in responses in relation to the present study.
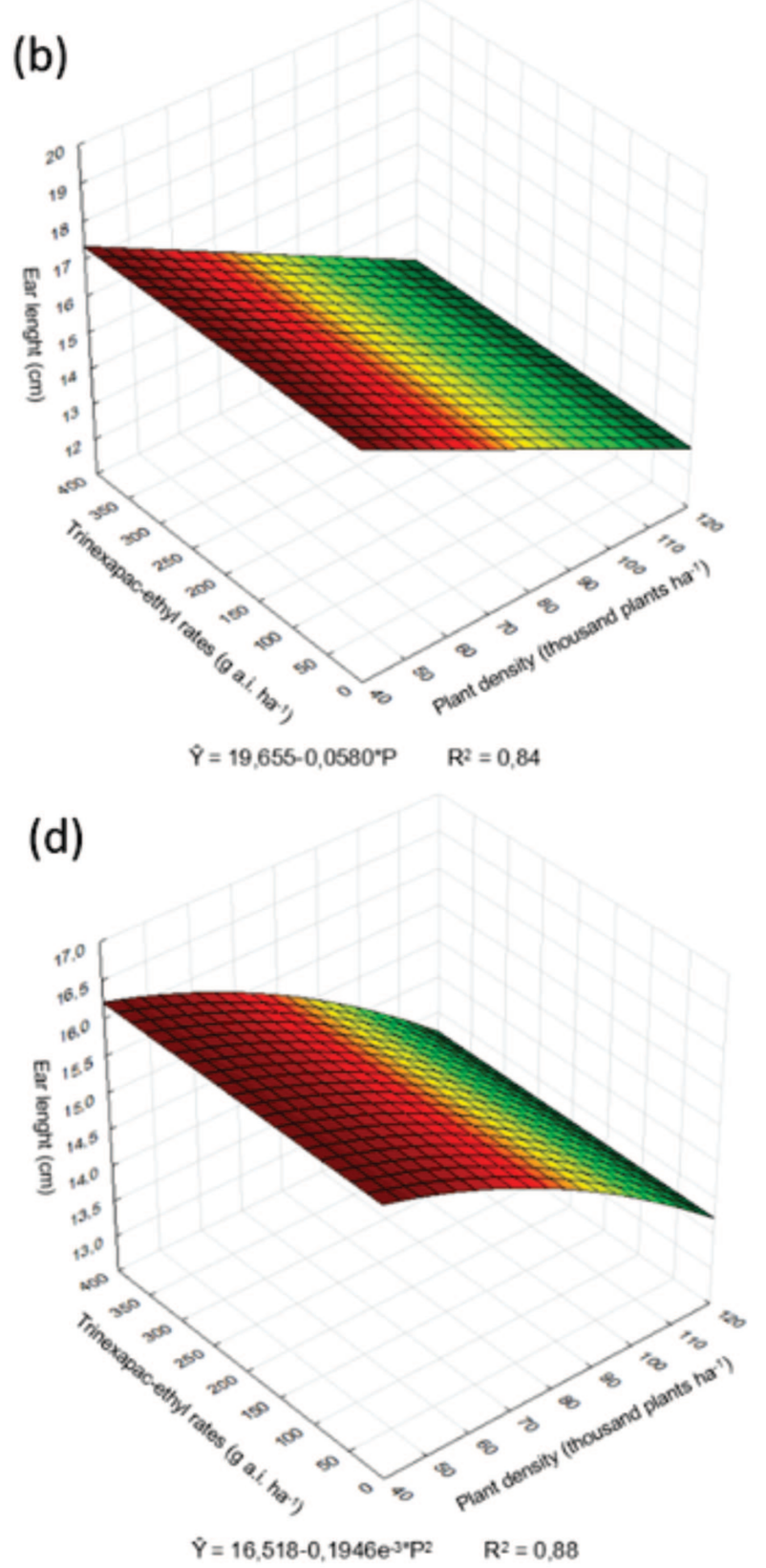

Figure 2: Length of ear of maize hybrids 2B710 HX (a and b) AND STATUS TL (c and d) in growing seasons 1 and 2 respectively, in response to plant densities and TE rates.

Rev. Ceres, Viçosa, v. 68, n.5, p. 401-410, sep/oct, 2021 
Normally, the effects on yield components and/or grain yield in wheat and rice are associated with modifications in the plant morphology caused by the product, in particular changes in plant height and leaf architecture (Arf et al., 2012; Alvarez et al., 2012; Espindula et al., 2009; Espindula et al., 2010). In this way, it is assumed that TE application induced morphological alterations in maize plants that optimized the exploitation of light incidence on the canopy, increasing the production of photoassimilates, favoring mainly the development of ovules at the tips of the ears, which increased the number of grains per row and ear length.

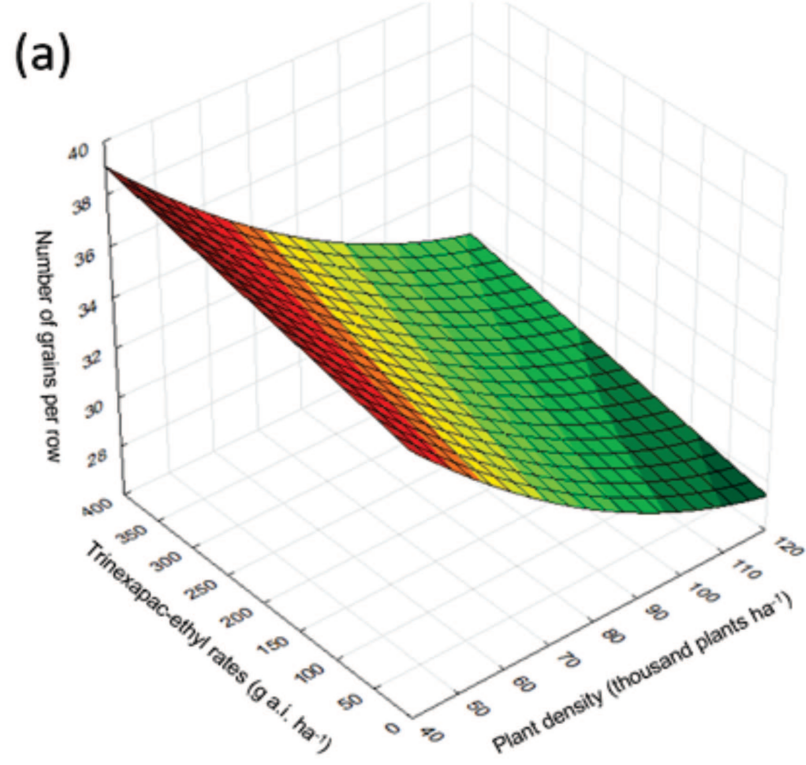

$\hat{Y}=45,324-0,2551^{*} P+0,0062^{*} T E+0,8830 e^{3 *} P^{2} \quad R^{2}=0,87$

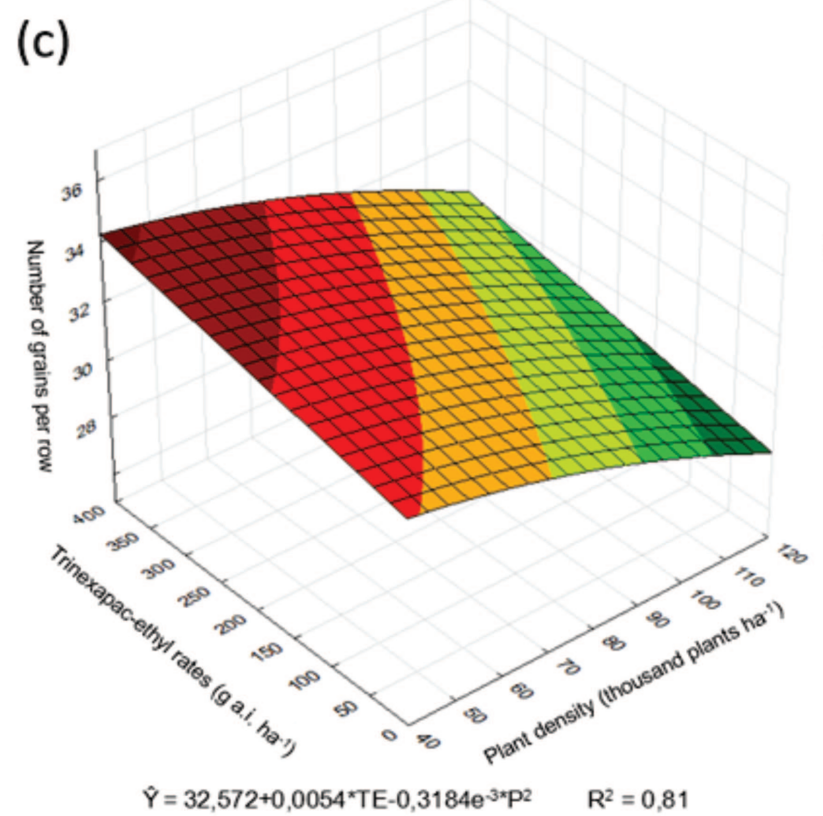

The increase in plant density reduced the 1000-grain mass, regardless of the growing season and hybrid (Figure 4). The reduction in grain mass due to increased plant density confirms the findings of Sangoi et al. (2009) and Lana et al. (2014).

The effect of TE on 1000-grain mass varied according to the maize hybrid. The 1000-grain mass of hybrid 2B710 HX declined under increasing TE rates, regardless of the growing season (Figures $4 \mathrm{a}$ and $4 \mathrm{~b}$ ). The increase in TE rates possibly reduced leaf area and plant height (stem), consequently reducing the quantity of assimilates for grain filling, as observed similarly for wheat by Espindula et al. (2009) and Espindula et al. (2011).
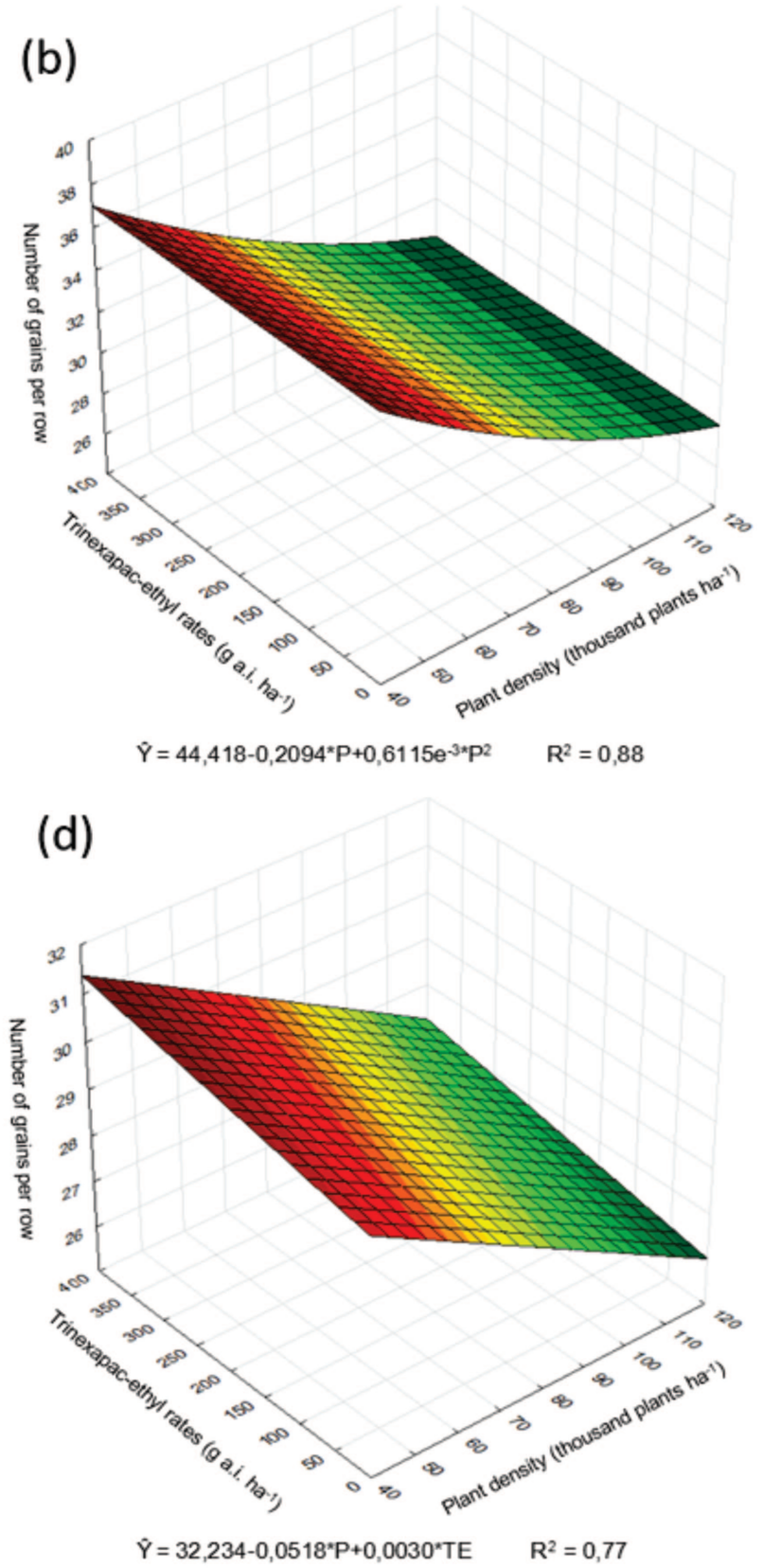

Figure 3: Number of grains per row of maize hybrids 2B710 HX (a and b) and STATUS TL (c and d) in the growing seasons 1 and 2 respectively, in response to plant densities and TE rates. 
No effect of TE on 1000-grain mass was observed in hybrid STATUS TL, in growing season 1 (Figure 4c). In growing season 2, a quadratic increase in 1000-grain mass was observed in response to TE applications, and the rate of $310 \mathrm{~g}$ a.i. ha ${ }^{-1}$ was related to the highest value (6.88 g) (Figure 4d). For the same hybrid, a similar result was observed by Zagonel \& Ferreira (2013), but the highest 1000-grain mass was obtained at a rate of $272 \mathrm{~g}$ a.i. $\mathrm{ha}^{-1}$. A quadratic increase in 1000-grain mass in wheat in response to the increase in TE rates was reported by Espindula $e t$ al. (2011), who explained this increase by a reduction in plant lodging.

\section{(a)}

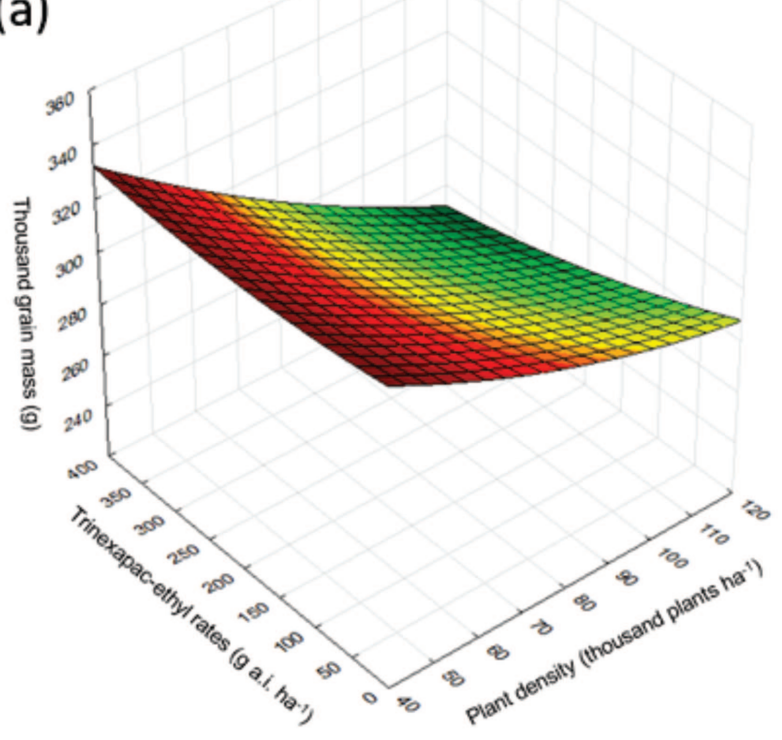

$\hat{Y}=374,71-1,158^{*} P+0,003^{*} P^{2}+0,950 e^{-4 *} T E^{2}-0,001^{*}\left(P^{*} T E\right) \quad R^{2}=0,90$

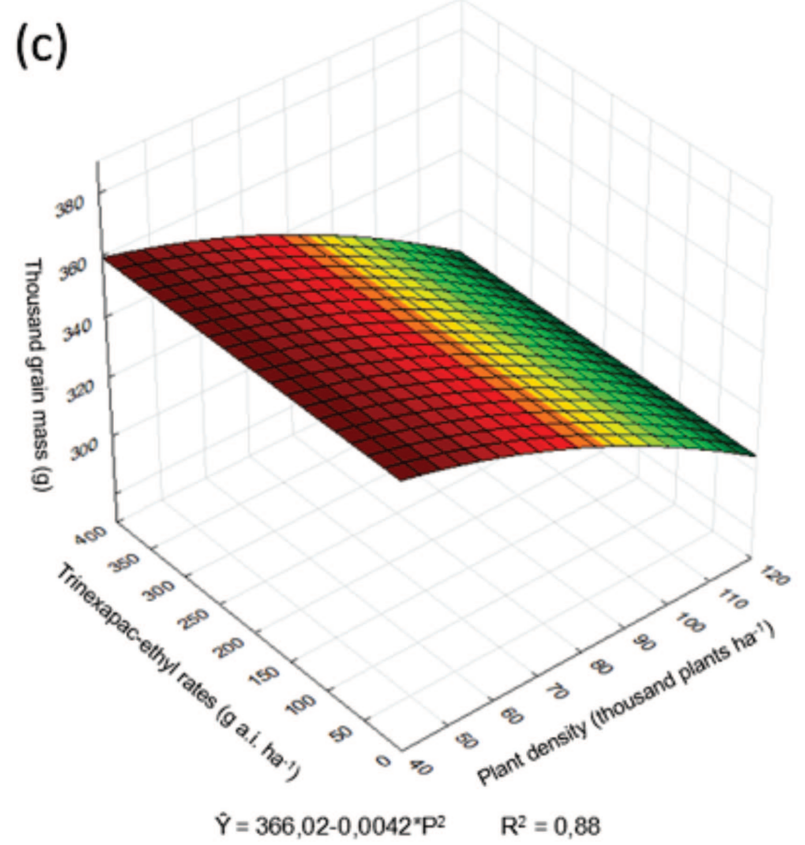

Regarding ear length and the number of grains per row, the use of growth regulator TE possibly promoted changes in the plant morphology, in particular in terms of plant height and architecture, resulting in a greater accumulation of photoassimilates in grains and a higher 1000-grain mass.

The grain yield of hybrid 2B710 HX was influenced by both factors studied, with independent effects of plant density and TE rates in both growing seasons (Figure 5a and 5b).

The increase in plant density increased the grain yield quadratically; in the absence of TE, yields were highest
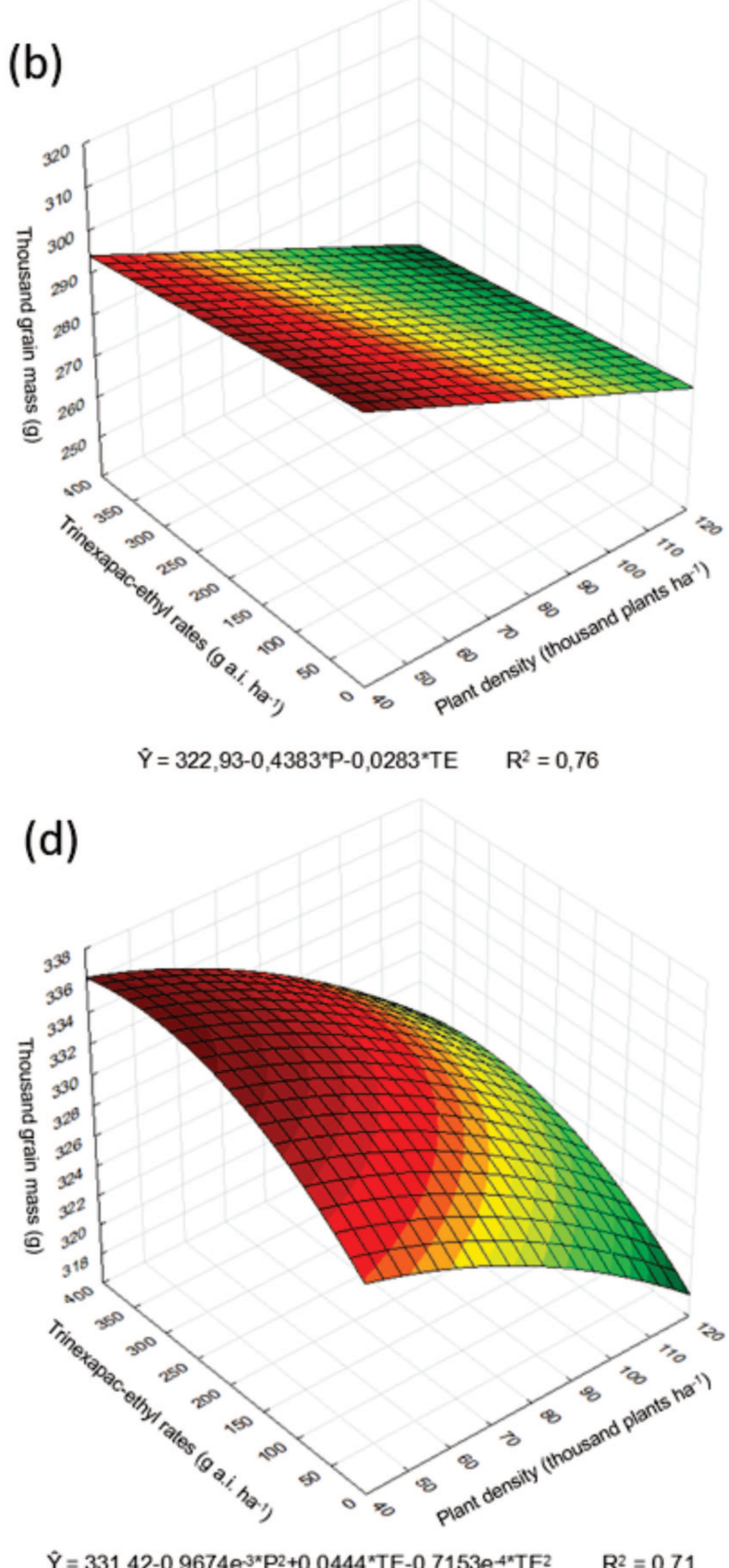

Figure 4: Thousand grain mass of maize hybrids 2B710 HX (a and b) and STATUS TL (c and d) in the growing seasons 1 and 2 respectively, in response to plant densities and TE rates. 
$\left(11,857.7\right.$ and $\left.11,712.5 \mathrm{~kg} \mathrm{ha}^{-1}\right)$ at densities of 93.4 and 87.1 thousand plants ha-1 in growing seasons 1 and 2, respectively. Thus, highest yields were obtained at plant densities exceeding the recommended by the holder of this hybrid (65 thousand plants ha-1), in both growing seasons. These results demonstrate that plant densities above the recommended range are possible, as long as the edaphoclimatic conditions are favorable and the cultivation practices are adequate as discussed by Assefa et al. (2018).

The response in grain yield to higher plant densities confirms results published elsewhere (Kappes et al., 2011; Sangoi et al., 2013). According to the above authors, grain

(a)

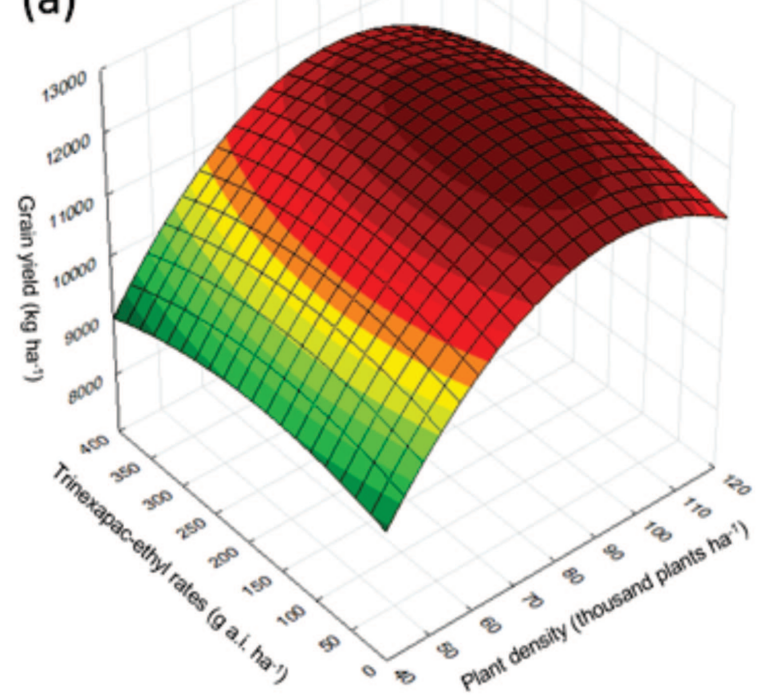

$\hat{\mathrm{Y}}=3667,3+175,32^{*} \mathrm{P}+3,7567^{*} \mathrm{TE}-0,9382^{*} \mathrm{P}^{2}-0,0107^{*} \mathrm{TE}^{2} \quad \mathrm{R}^{2}=0,93$
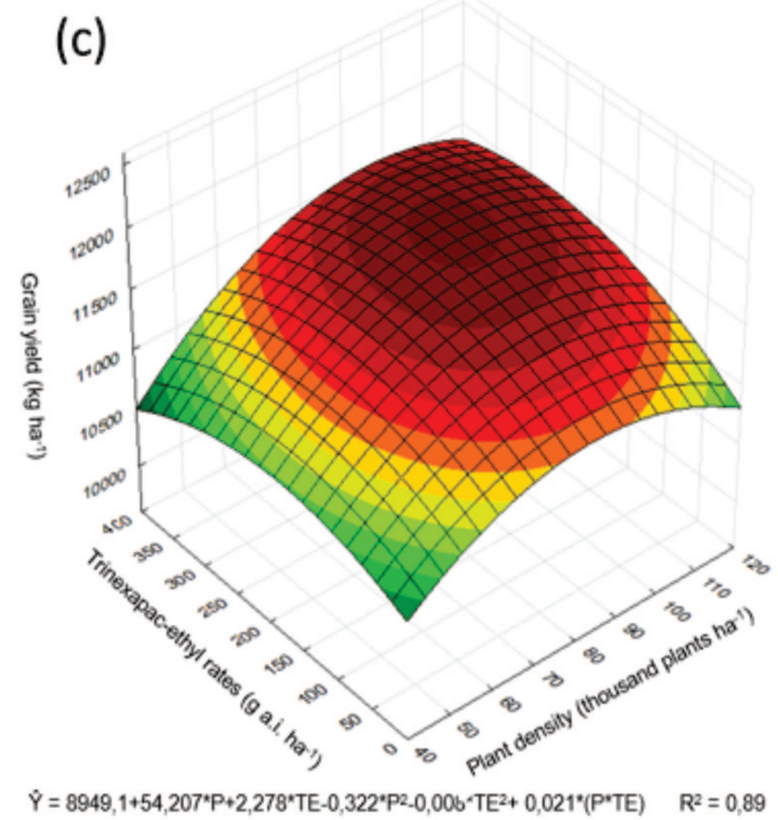

yield per unit area increases linearly with the increase in plant density, up to a point called "critical". However, above the critical population level, due to the competition between the maize plants, the yield per plant decreases and grain yield per area has a quadratic adjustment. At densities above this point of maximum production per area, the loss of individual production is greater than the gain with increase of plants per area, promoting a reduction in grain yield per hectare.

For hybrid 2B710, distinct responses in grain yield were observed in the two growing seasons in relation to TE application. In growing season 1, the growth regulator
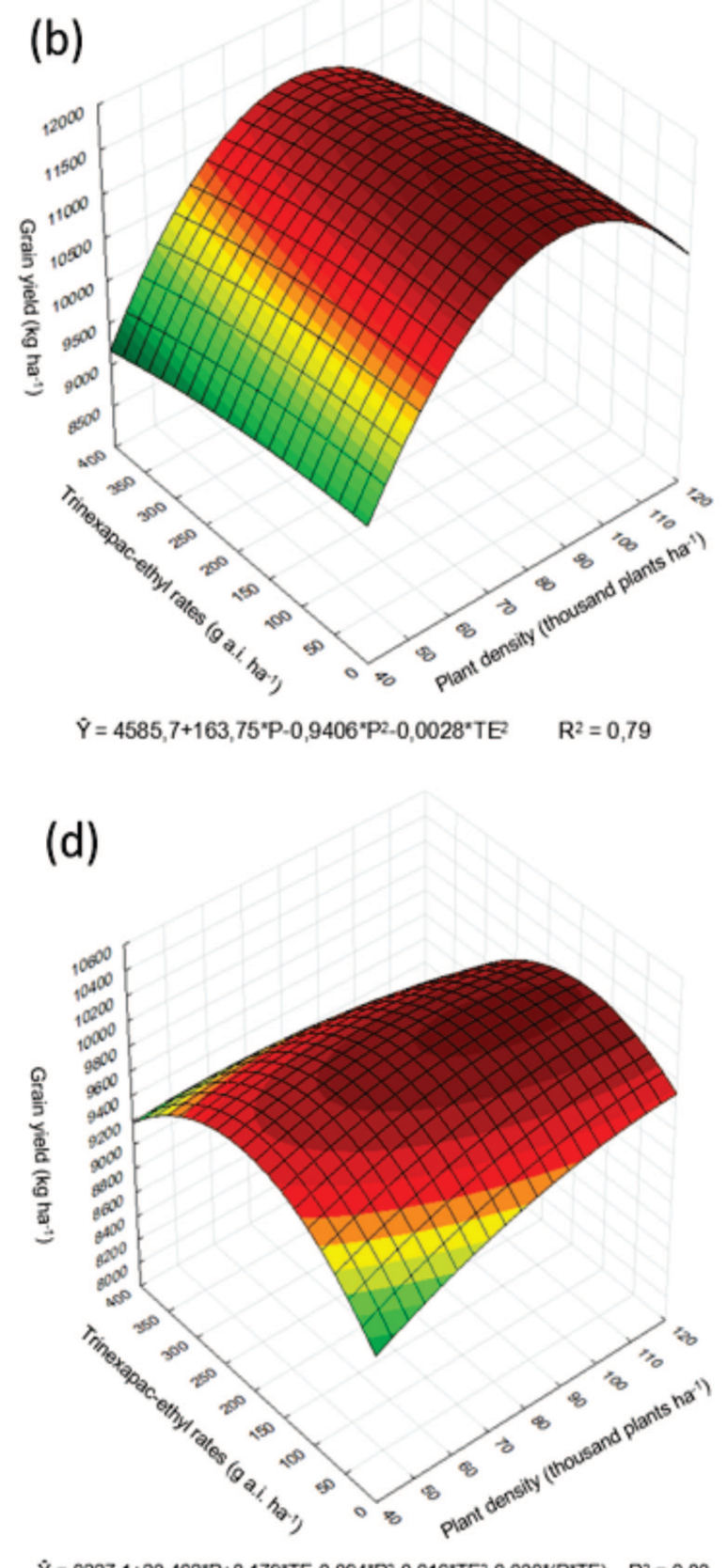

$\dot{\gamma}=8227,1+23,462^{*} \mathrm{P}+8,179^{*} \mathrm{TE}-0,094^{*} \mathrm{P}^{2}=0,016^{\circ} \mathrm{TE}^{2}-0,030^{*}$ (P*TE) $^{*} \mathrm{R}^{2}=0,83$

Figure 5: Grain yield of maize hybrids 2B710 HX (a and b) and STATUS TL (c and d) in growing seasons 1 and 2 respectively, in response to plant densities and TE rates. 
induced a quadratic increase, with a maximum increment of $329.7 \mathrm{~kg} \mathrm{ha}^{-1}$ at a rate of $176 \mathrm{~g}$ a.i. ha ${ }^{-1}$, regardless of the plant density (Figure 6a). However, in growing season 2, TE reduced the grain yield, reaching $448.0 \mathrm{~kg} \mathrm{ha}^{-1}$ at the highest rate (Figure 5b). A reduction in grain yield in response to TE application was also reported for upland rice by Alvarez et al. (2012) and Alvarez et al. (2014) and in wheat by Contreras et al. (2012).

Possible morphological changes caused by TE application in growing season 1 on plant height and ear insertion height, leaf area index, leaf length, leaf width, leaf angle, and arrangement of maize leaves improved the exploitation of the incident solar radiation, favoring photoassimilate production, raising grain yields. Extensive studies in the literature report the same pattern of increased grain yield in response to TE applications to rice, oat and wheat (Espindula et al., 2009; Nascimento et al., 2009; Espindula et al., 2011; Arf et al., 2012).

The difference in the hybrid response between the two growing seasons was possibly due to the interaction between the factors studied and the climate factors in each growing season. According to Penckowski \& Fernandes (2010), the response in wheat to TE application is directly linked to aspects such as soil texture, fertility level and meteorological conditions.

Most likely, the absence of pluvial precipitation in growing season 2, in the period between January 29 and February 27 (Figure 1a), may have affected the response of hybrid 2B710 HX to the TE rates. According to Radin et al. (2003), the water demand of maize in this period (stages R3 and R4) is approximately $150 \mathrm{~mm}$, while within a period of 30 days, only $10.1 \mathrm{~mm}$ rain was registered. The lack of water available to plants in this period coincided with the phases of grain development and filling, during which cell division/ expansion and starch accumulation in maize grains occur with greater intensity, thus compromising the grain development and the response of the hybrid to TE. The same influence of water stress on the yield response of hybrid $2 \mathrm{~B} 710 \mathrm{HX}$ to TE rates is reflected in the yield components, where a reduction in 1000-grain mass and a lack of response in the other components was stated. In fact, the application of TE to wheat is not recommended in case of drought occurrence during crop development.

For the grain yield of hybrid STATUS TL, a significant interaction was observed between the factors plant densities and TE rates (Figure 5).

In relation to the increase in plant density, yield responded quadratically in both growing seasons. However, in the absence of TE, the highest yield of growing season 1 was obtained at a density of 84.0 thousand plants ha-1, which produced $11,225 \mathrm{~kg} \mathrm{ha}^{-1}$ (Figure $5 \mathrm{c})$. In growing season 2 , the highest yield $(9,689 \mathrm{~kg}$ $\mathrm{ha}^{-1}$ ) was obtained at a density of 120 thousand plants ha-
${ }^{1}$, and, in spite of a quadratic response, the point of highest yield (critical point) was not achieved with the plant densities studied here (Figure 5d).

The yield response to a higher plant density in growing season 1 confirmed the observation for hybrid 2B710 HX, as well as other studies evaluating the same cause of variation (Kappes et al., 2011; Sangoi et al., 2013).

The quadratic response of grain yield to a higher plant density in maize is frequent, however, in some cases, due to the peculiarity of the genotype -environment interaction, the yield can be increased according to the increase in the plant population without reaching the critical yield, as observed in growing season 2 and in a study of Kappes et al. (2011).

In both growing seasons, the population that produced the highest grain yield was higher than the population recommended by the holder of hybrid STATUS TL $\left(\right.$ Syngenta $\left.^{\circledR}\right)$, i.e., 70 thousand plants ha-1 ${ }^{-1}$ The results show that the genotype - environment interaction in both seasons had a favorable setting for grain yield at higher plant densities.

Due to the significant interaction between plant density and TE rate, the plant density for the highest grain yield (critical point) was changed according to the year of cultivation, where TE accounted for increases in grain yield in both growing seasons.

In growing season 1, the highest yield of hybrid STATUS TL was obtained at a density of 92.2 thousand plants ha ${ }^{-1}$ combined with TE rates of $251.0 \mathrm{~g}$ a.i. ha ${ }^{-1}$, corresponding to $11,731.6 \mathrm{~kg} \mathrm{ha}^{-1}$. This new critical point resulted in a $506 \mathrm{~kg} \mathrm{ha}^{-1}$ higher yield than the maximum yield observed in the absence of TE ( 84 thousand plants ha $^{-1}$ ) (Figure 5c).

In growing season 2, based on the increases induced by TE application, the plant density related to the highest yield was reduced to 99.0 thousand plants $\mathrm{ha}^{-1}$ associated with a TE rate of $157.5 \mathrm{~g}$ a.i. ha $^{-1}$, providing a grain yield of $10,032.1 \mathrm{~kg} \mathrm{ha}^{-1}$, i.e. $343.2 \mathrm{~kg} \mathrm{ha}^{-1}$ higher than the yield without TE (Figure 5d).

Aside from the positive effect of TE application on grain yield of hybrid STATUS TL, it was observed that under normal rainfall conditions (growing season 1), TE promoted a greater increase in yield when related to higher plant densities (Figure 1a). However, due to the occurrence of water stress in growing season 2, the highest increases were observed when associated with smaller populations (Figure 1b).

Possible changes in the plant morphology in response to TE application reduced the negative effects of high plant densities, optimizing the exploitation of incident solar radiation, increasing maize ear length, number of grains per row and 1000-grain mass, increasing the grain yield of the studied hybrids. A similar result was described for 
wheat by Nascimento et al. (2009), where the authors obtained a reduction in plant height and lodging, which resulted in more compact plants with improved transport of photoassimilates to the grains, increasing the 1000grain mass, hectoliter mass and grain yield.

According to Zagonel \& Ferreira (2013), the response of maize to TE application is not frequently observed and varies according to factors such as climate, cultivar, rate and application time. This statement is confirmed by a comparison with the results of those authors and our study, in which the former observed no effect of TE rates and application times on hybrid STATUS TL, contrary to our results.

The effects of plant density and TE rates were more beneficial for cultivation in growing season 1 , due to the better rainfall conditions that favored the yield performance of the crop.

In specific situations, some yield components can be reduced by increasing TE rates, although the growth regulator induced increases in most yield components studied here, in particular in ear length and number of grains per row. Thus, the possibility of using higher plant densities due to changes in the plant morphology caused by TE tends to further maximize yields by increasing the number of plants and ears per area.

Based on the assumption that TE would provide better results for hybrid $2 \mathrm{~B} 710 \mathrm{HX}$, due to its characteristic of plane leaves, it was observed that TE increased the yield components and grain yield of this hybrid, however, more pronounced gains were observed in both growing seasons for hybrid STATUS TL, which has upright leaves. Thus, it can be concluded that even the yield potential of hybrids with plant characteristics adapted to high plant densities may be optimized by the use of the technology of growth regulators.

The results of this study demonstrate the potential of using growth regulators, mainly of TE, as a promising management technique to optimize the exploitation of solar radiation by maize by increasing the grain yield. In addition, the reduction in plant height caused by TE can favor the application of products for phytosanitary control in the maize crop, especially in trawling equipment. However, the variability of results observed according to the hybrid and growing season makes it clear that the application of growth regulators is not that simple, since factors inherent to the cultivation conditions, e.g. of the cultivar, soil fertility, plant nutrition and climate conditions, are fundamental to ensure positive results. Thus, there is a need for continuous studies of growth regulator application in maize, where their interaction with management techniques such as plant arrangement, sowing date and nitrogen fertilization are aspects to be investigated in new studies.

\section{CONCLUSIONS}

The increase in plant density increases the number of ears per hectare but reduces ear length, number of grains per row and 1000-grain mass, without changing the number of grain rows per ear.

Growth regulator TE increases maize ear length and number of grains per row and reduces 1000-grain mass, mainly under favorable cultivation conditions.

Trinexapac-ethyl interacts with plant density, changing the maize yield components with increasing grain yield, with gains varying according to the environment and characteristics of the cultivar.

\section{ACKNOWLEDGEMENTS, FINANCIAL SUPPORT AND FULL DISCLOSURE}

To the researchers, that constituted the doctoral bank of the first author for their useful comments and suggestions that greatly improved the quality of the manuscript.

The authors declare no conflicts of interest in the conduct and publication of this work.

\section{REFERENCES}

Alvarez RCF, Crusciol CAC \& Nascente AS (2014) Produtividade de arroz de terras altas em função de reguladores de crescimento. Revista Ceres, 61:42-49.

Alvarez RCF, Crusciol CAC, Nascente AS, Rodrigues JD \& Habermann G (2012) Gas exchange rates, plant height, yield components, and productivity of upland rice as affected by plant regulators. Pesquisa Agropecuária Brasileira, 47:14551461.

Arf O, Nascimento V, Rodrigues RAF, Alvarez RCF, Gitti DC \& Sá ME (2012) Uso de etil-trinexapac em cultivares de arroz de terras altas. Pesquisa Agropecuária Tropical, 42: 150-158.

Assefa Y, Carter P, Hinds M, Bhalla G, Schon R, Jeschke M, Paszkiewicz S, Smith S \& Ciampitti IA (2018) Analysis of long term study indicates both agronomic optimal plant density and increase maize yield per plant contributed to yield gain. Scientific Reports, 8: 4937.

Brachtvogel EL, Pereira FRS, Cruz SCS \& Bicudo SJ (2009) Densidades populacionais de milho em arranjos espaciais convencional e equidistante entre plantas. Ciência Rural, 39:23342339.

Brasil (2009) Regras para análise de sementes. Brasília, Ministério da Agricultura e Reforma Agrária. 399p.

Contreras RLG, Duarte RM, Díaz GM, Contreras FR \& Ramirez FN (2012) Effects of trinexapac-ethyl on different wheat varieties under desert conditions of Mexico. Agricultural Sciences, 3:658-662.

Davies PJ (1987) The plant hormones: their nature, occurrence, and functions. In: Davies PJ (Ed.) Plant hormones and their role in plant growth and development. Netherlands, Kluwer Academic. p.1-23.

Espindula MC, Rocha VS, Fontes PCR, Silva RCC \& Souza LT (2009) Effect of nitrogen and trinexapac -ethyl rates on the spad index of wheat leaves. Journal of Plant Nutrition, 32:19561964.

Rev. Ceres, Viçosa, v. 68, n.5, p. 401-410, sep/oct, 2021 
Espindula MC, Rocha VS, Souza LT, Souza MA, Campanharo M \& Grossi JAS (2011) Rates of nitrogen and growth retardant trinexapac-ethyl on wheat. Ciência Rural, 41:2045-2052.

Espindula MC, Rocha VS, Souza LT, Souza MA \& Grossi JAS (2010) Efeito de reguladores de crescimento na elongação do colmo de trigo. Acta Scientiarum Agronomy, 32:109-116.

Gong L, Qu S, Huang G, Guo Y, Zhang M, Li Z, Zhou Y \& Duan L (2012) Improving maize grain yield by formulating plant growth regulator strategies in North China. Journal of Integrative Agriculture, 20:622-632

Kappes C, Andrade JAC, Arf O, Oliveira AC, Arf MV \& Ferreira JP (2011) Arranjo de plantas para diferentes híbridos de milho. Pesquisa Agropecuária Tropical, 41:348-359.

Lana MC, Rampim L, Ohland T \& Fávero F (2014) Spacing, population density and nitrogen fertilization in corn grown in an Oxisoil. Revista Ceres, 61:424-433.

Leolato LS, Sangoi L, Durli MM, Panison F \& Voss R (2017) Growth regulator and maize response to the increase in plant density. Pesquisa Agropecuária Brasileira, 52:997-1005.

Marchão RL, Brasil EM \& Ximenes PA (2006) Interceptação da radiação fotossinteticamente ativa e rendimento de grãos de milho adensado. Revista Brasileira de Milho e Sorgo, 5:170181 .

Nascimento V, Arf O, Silva MG, Binotti FFS, Rodrigues RAF \& Alvarez RCF (2009) Uso de regulador de crescimento etiltrinexapac em arroz de terras altas. Bragantia, 68:921-929.

Penckowski LH \& Fernandes EC (2010) Utilizando regulador de crescimento na cultura do trigo: Aspectos importantes para garantir bons rendimentos. Castro, Fundação ABC. 68p.
Penckowski LH, Zagonel J \& Fernandes EC (2009) Nitrogênio e redutor de crescimento em trigo de alta produtividade. Acta Scientiarum Agronomy, 31:473-479.

Radin B, Bergamaschi H, Santos AO, Bergonci JI \& França S (2003) Evapotranspiração da cultura do milho em função da demanda evaporativa atmosférica e do crescimento das plantas. Pesquisa Agropecuária Gaúcha, 9:7-16.

Ritchie SW, Hanway JJ \& Benson GO (2003) Como a planta de milho se desenvolve. Piracicaba, Potafos. 20p.

Sangoi L, Durli MM, Souza CA, Leolato LS, Kuneski HF \& Coelho AE (2020) Maize response to trinexapac-ethyl and nitrogen fertilization. Planta Daninha, 38:e020185014.

Sangoi L, Schmitt A, Saldanha A, Fiorentin CF, Pletsch AJ, Vieria F \& Gattelli MA (2009) Rendimento de grãos de híbridos de milho em duas densidades de plantas com e sem a retirada de perfilhos. Ciência Rural, 39:325-331.

Sangoi L, Schweitzer C, Silva PRF, Schmitt A, Vargas VP, Casa RT \& Souza CA (2011) Perfilhamento, área foliar e produtividade do milho sob diferentes arranjos espaciais. Pesquisa Agropecuária Brasileira, 46:609-616

Sangoi L, Zanin CG, Schmitt A \& Vieira J (2013) Senescência foliar e resposta de híbridos de milho liberados comercialmente para cultivo em diferentes épocas ao adensamento. Revista Brasileira de Milho e Sorgo, 12:21-32.

Zagonel J \& Fernandes EC (2007) Doses e épocas de aplicação de redutor de crescimento afetando cultivares de trigo em duas doses de nitrogênio. Planta Daninha, 25:331-339.

Zagonel J \& Ferreira C (2013) Doses e época de aplicação de regulador de crescimento em híbridos de milho. Planta Daninha, 31:395-402. 